\title{
Republican learning
}

JOHN TOLAND AND THE CRISIS OF CHRISTIAN CULTURE， 1696-1722

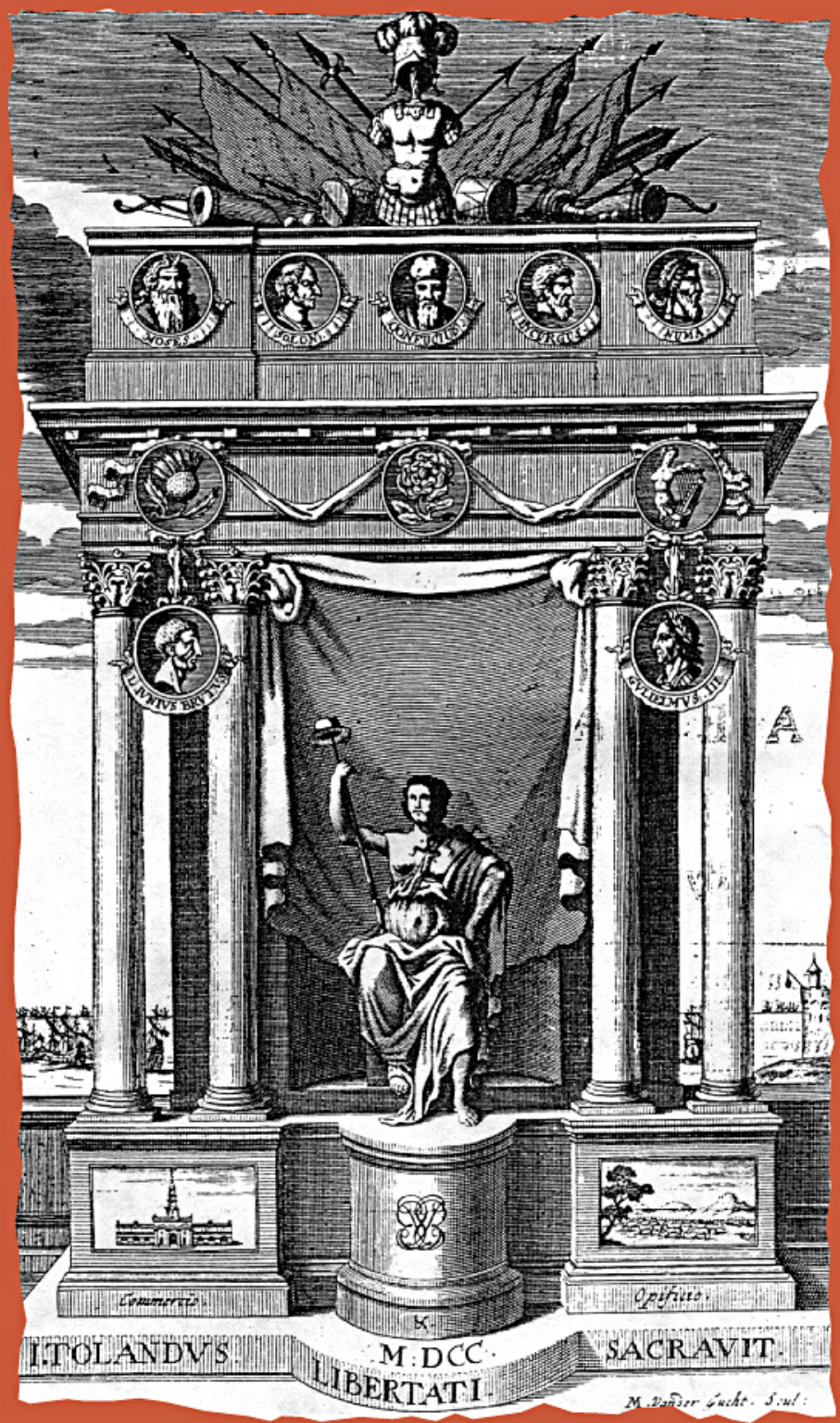

J U S T I N C H A M I O N 


\section{Republican learning}

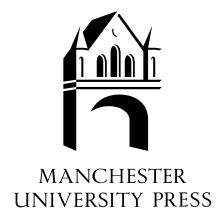


Politics, culture and society in early modern Britain

\author{
General editors \\ PROFESSOR ANN HUGHES \\ DR ANTHONY MILTON \\ PROFESSOR PETER LAKE
}

This important series publishes monographs that take a fresh and challenging look at the interactions between politics, culture and society in Britain between I500 and the mid-eighteenth century. It counteracts the fragmentation of current historiography through encouraging a variety of approaches which attempt to redefine the political, social and cultural worlds, and to explore their interconnection in a flexible and creative fashion. All the volumes in the series question and transcend traditional interdisciplinary boundaries, such as those between political history and literary studies, social history and divinity, urban history and anthropology. They contribute to a broader understanding of crucial developments in early modern Britain.

Already published in the series

Leicester and the Court: essays on Elizabethan politics SIMON ADAMS

Ambition and failure in Stuart England: the career of John, first Viscount Scudamore IAN ATHERTON

The idea of property in seventeenth-century England: tithes and the individual LAURA BRACE

Betting on lives: the culture of life insurance in England, 1695-1775 GEOFFREY CLARK

Home divisions: aristocracy, the state and provincial conflict THOMAS COGSWELL

A religion of the world: the defence of the reformation in the reign of Edward VI CATHARINE DAVIES

Cromwell's major-generals: godly government during the English Revolution CHRISTOPHER DURSTON

Urbane and rustic England: cultural ties and social spheres in the provinces, 1660-1780 CARL B. ESTABROOK

The English sermon revised: religion, literature and history $1600-1750$

LORI ANNE FERRELL and PETER MCCUlLOUgh (eds)

The spoken word: oral culture in Britain 1500-1850 ADAM FOX and DANIEL WOOLF (eds)

Londinopolis: essays in the cultural and social history of early modern London PAUL GRIFFITHS AND MARK JENNER (eds)

Inventing a republic: the political culture of the English Commonwealth 1649-1653 SEAN KELSEY

The box maker's revenge: 'orthodoxy', 'heterodoxy' and the politics of parish in early Stuart London PETER LAKE

Theatre and empire: Great Britain on the London stages under James VI and I TRISTAN MARSHALL

Courtship and constraint: rethinking the making of marriage in Tudor England DIANA O'HARA

Communities in early modern England: networks, place, rhetoric ALEXANDRA SHEPARD and PHILIP WITHINGTON (eds)

Aspects of English Protestantism, c. 1530-1700 NICHOLAS TYACKE

Political passions: gender, the family and political argument in England, 1680-1714 RACHEL WEIL 


\title{
Republican learning
}

\author{
John Toland and the crisis \\ of Christian culture, I696-I722 \\ JUSTIN CHAMPION
}

\author{
Manchester \\ University Press
}

Manchester and New York

distributed exclusively in the USA by Palgrave 
Copyright (C) Justin Champion 2003

The right of Justin Champion to be identified as the author of this work has been asserted by him in accordance with the Copyright, Designs and Patents Act I988.

Published by Manchester University Press

Oxford Road, Manchester MI3 9NR, UK

and Room 400, I75 Fifth Avenue, New York, NY IooIo, USA

www.manchesteruniversitypress.co.uk

Distributed exclusively in the USA by

Palgrave, I75 Fifth Avenue, New York, NY IooIo, USA

Distributed exclusively in Canada by

UBC Press, University of British Columbia, 2029 West Mall,

Vancouver, BC, Canada v6T IZ2

British Library Cataloguing-in-Publication Data

A catalogue record for this book is available from the British Library

Library of Congress Cataloging-in-Publication Data applied for

ISBN 071905714 ○ hardback

First published 2003

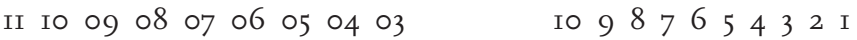

Typeset in Scala with Pastonchi display

by Koinonia Ltd, Manchester

Printed in Great Britain

by Bookcraft (Bath) Ltd, Midsomer Norton 